International Journal of Advanced Research in Engineering and Technology (IJARET)

Volume 11, Issue 7, July 2020, pp. 395-405, Article ID: IJARET 1107039

Available online athttp://iaeme.com/Home/issue/IJARET?Volume $=\overline{1} 1 \& \overline{\mathrm{I}} \mathrm{ssue}=7$

ISSN Print: 0976-6480 and ISSN Online: 0976-6499

DOI: 10.34218/IJARET.11.7.2020.039

(C) IAEME Publication

Scopus Indexed

\title{
FIGHTING COVID-19 WITH TECHNOLOGY AND INNOVATION, EVOLVING AND ADVANCING WITH TECHNOLOGICAL POSSIBILITIES
}

\author{
Dr. Navleen Kaur \\ Associate Professor, Amity International Business School, \\ Amity University Noida, Uttar Pradesh, India \\ Supriya Lamba Sahdev \\ Assistant Professor, Amity International Business School, \\ Amity University Noida, Uttar Pradesh, India \\ Vaibhav Chaturvedi \\ Student, Amity International Business School, \\ Amity University Noida, Uttar Pradesh, India \\ Dhruv Rajawat \\ Student, Amity International Business School, \\ Amity University Noida, Uttar Pradesh, India
}

\begin{abstract}
Various sectors have seen tremendous growth after Covid 19 breakdown. Covid 19 has dramatically changed the way we live and work. It has changed the way business used to run in the past. After outbreak of this pandemic and lockdown in various countries, there has been number of businesses which have moved from offline mode to online mode. The utmost affected businesses were those which run only through offline mode and where the transition from offline to online is not possible. Most of the businesses today are trying to go online where this transition is possible. It is said that 'Necessity is the mother of all inventions'; businesses are coming out with innovative ways to grow and excel.

The businesses which have gained the most include OTT (Over the Top) platforms such as Netflix, Amazon Prime, Hotstar etc. Movies are being released directly on these platforms now, which were earlier released on theatres and multiplexes. Lockdown has forced cinema, to down shutters in the wake of pandemic. For film industry to run its business, it must release movies on OTT platform. OTT platform is flourishing whereas multiplexes are tumbling because of the pandemic.
\end{abstract}


Fighting Covid-19 with Technology and Innovation, Evolving and Advancing with Technological Possibilities

The other businesses which boomed are the e-commerce companies such as flipkart, amazon, and grocery online supermarkets such as grofers, big basket etc. as people now prefer to buy online instead of going to the market as a precautionary and safety measure. This is leading to increase in sales of e-commerce companies. This ecommerce boom is affecting offline retail stores. Reliance has launched its online store JioMart in wake of this, taking the advantage of perfect timing.

Videoconferencing platforms such as MsTeams, Zoom, Google Meet, Webex etc. are helping people and businesses to remain connected and work from home during lockdown. Education Technology companies such as Amity Future Academy, Byjus, Coursera, Udemy etc. are making online teaching a new normal.

We are truly becoming a Digital World after the advent of Covid-19. This paper explores the technological trends during Covid-19 pandemic.

Key words: Innovations during pandemic, covid-19 and technology, technological trends in covid-19 era, corona virus innovations, artificial intelligence and covid-19, trends towards digital world, advanced research in technology.

Cite this Article: Dr. Navleen Kaur, Supriya Lamba Sahdev, Vaibhav Chaturvedi and Dhruv Rajawat, Fighting Covid-19 with Technology and Innovation, Evolving and Advancing with Technological Possibilities, International Journal of Advanced Research in Engineering and Technology, 11(7), 2020, pp. 395-405.

http://iaeme.com/Home/issue/IJARET?Volume=11\&Issue=7

\section{INTRODUCTION}

Everything was running smoothly; our lives were on track. The 21 st century was blooming like any other day until we could know our unpredictable future.

An outbreak of novel corona virus $(2019-\mathrm{nCoV})$ began in the city of China, Wuhan which rapidly spread with confirmed cases in many countries. The virus showed the symptoms of fatigue, sour throat, high fever etc. Later, travel related transmission were observed in various countries which raised the situation of global health emergency. Virus spread rapidly across the countries causing deaths and trauma around the globe. Gradually, it went out of control as it started spreading by infected humans and surface contact, more and more people went into quarantine. The symptoms advanced to respiratory illness and lung failure. One by one countries started shutting themselves from public places to international and domestic transport, schools, colleges, restaurants, courts, shopping malls, gymnasiums, salons, everything was evacuated.

The virus expanded wildly throughout the globe that humans were forced to sit home. Lockdown has been imposed in all the countries it was an emergency protocol which prevented people from leaving a given area.

The pandemic situation made people live by technology, they started working from home through web cameras and video conferencing portals. From corporate sectors to judiciary everyone is working online through technology. Education and learning also took place through online platforms. Digital technology has brought new innovations in challenging time

Many of us have been already using phones, digital media and other artificial gadgets in our day to day lives, but during the current scenario of pandemic, technology has become even more important to us. During the lockdown, everyone tried to abstain from going out and doing their work, but technology made the work easier and flexible. The economy of the countries is not dragging to worst situation just because of the new age technology. Many corporate companies are running online, having their meetings through online portals like 
Zoom, Microsoft Teams and Google Meet. Education is also not in much trouble due to the online classes through these portals. On the top of this, plethora of mental health apps are helping to control anxiety and stress. Many apps have been made to track the health and situation of COVID -19. The heaviest demand ever in time, has been the increase in demand of video games, online games. They are finding place in every home. With all this how could we forget our favorite social media and online streaming services like Netflix, Amazon Prime. These all upgraded technologies have become the survivor for this challenging situation. They all have added value not only to professional but personal lives too.

\section{INNOVATION IN THE ERA OF COVID-19}

Epidemics and pandemics have rooted the world since ages. From H1N1, Ebola, SARS we have been learning to develop ourselves more with the advent of each outbreak. Technology couldn't vanish the situations but could help in its spreading, empowering and warning people. There was an increase in the demand of hand sanitizers and masks which led to immense shortage of the both. So, to fight the shortage new 'Automatic Mask Machines' manufactured masks which were $40 \%$ cheaper than imported masks.

Rudhaar a very low-cost ventilator was launched together, by the team of scientists and engineers in India. Just like Rudhaar, Jeeva Setu ventilator by REVA University was an innovation. An Indian Navy doctor developed a very low-cost PPE kit "NavRakshak". These PPE kits are made of breathable fabric and could be used in hot and humid weather conditions.

Wireless thermometers which detects the temperature within some distance without actually touching the people are being seen at offices, airports, hospitals, railway stations and at other crowded places. Innovation of robotic technology in healthcare system, businesses etc. is a step forward to fight with the virus. There is no stop in the use of technology and innovation in the challenging situation of pandemic. This technological advancement has made us reach to the far better conditions, which would not have been possible without data science.

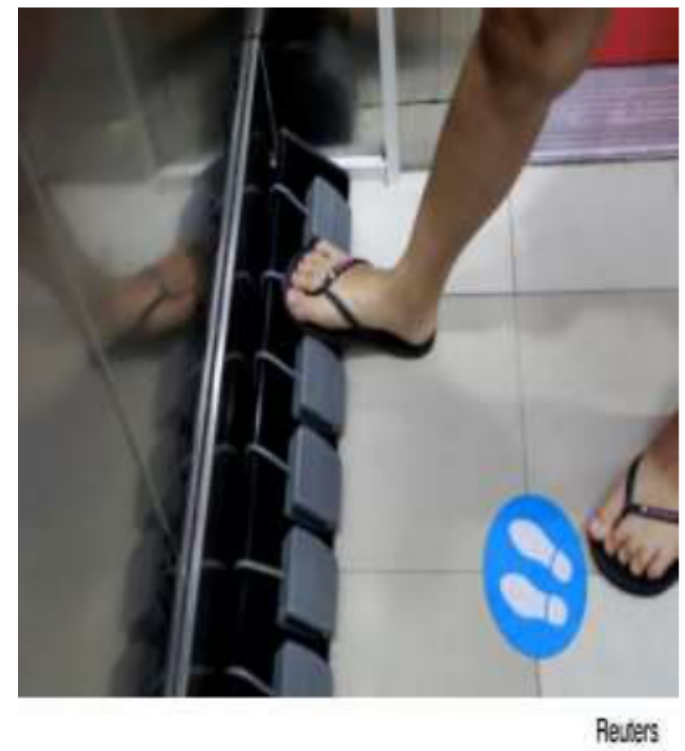

Figure 1 Foot pedals in lifts at Thai mall.

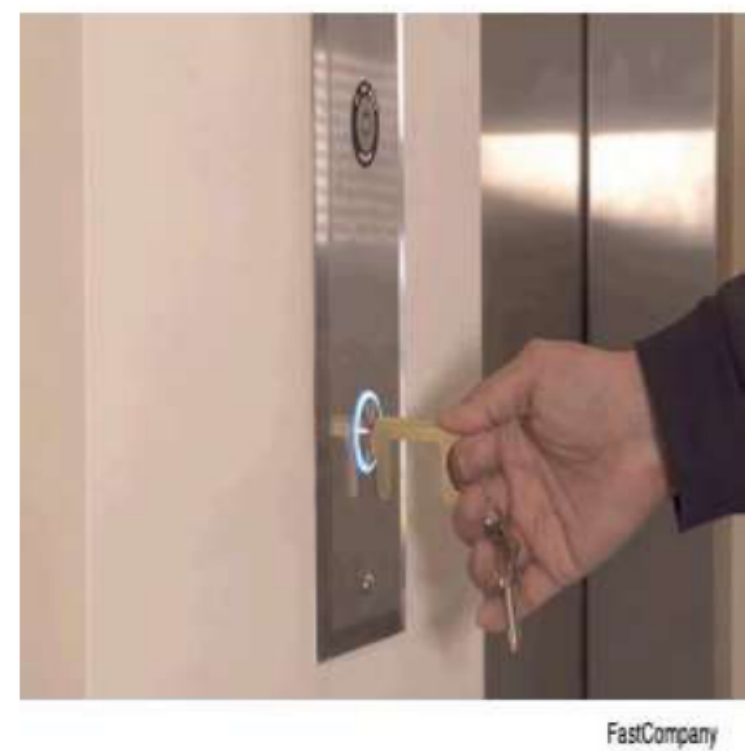

Figure 2 Hygiene hand that touches elevator button, ATM, phone screen for you (designed by New York city paramedic) 


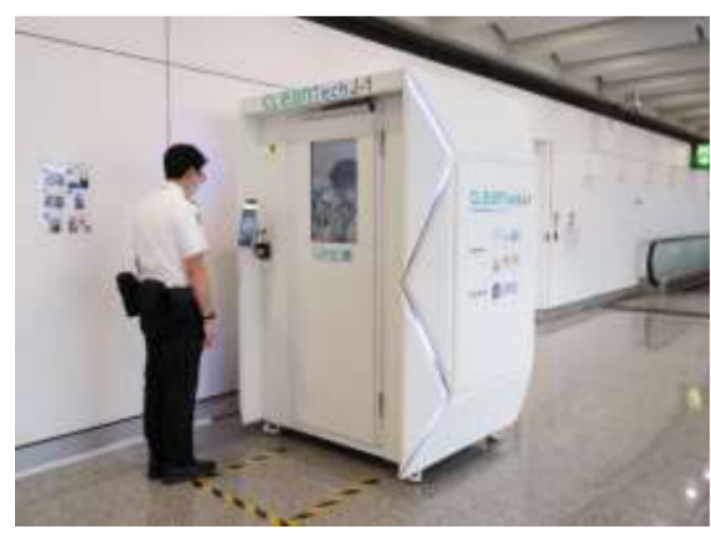

Figure 3 Forbes Disinfectant enclosures

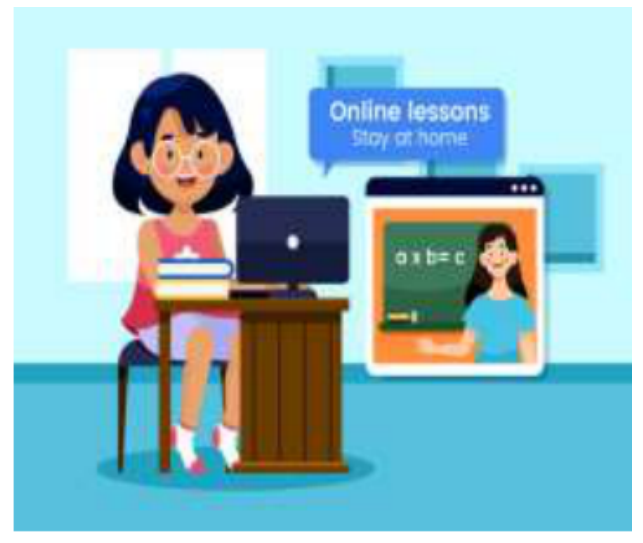

Figure 4 courtesy: freepik.com /Online teaching

\section{REVIEW OF LITERATURE}

(Mihalis Kritikos, 2020) of the Scientific Foresight Unit (STOA) analysed in detail how ten different technological domains are helping to fight against the pandemic disease by means of innovative applications. It sheds light on the main legal and regulatory challenges and on the key socio-ethical dilemmas that the various uses of these technologies pose when applied in a public-health emergency context such as the Covid 19 pandemic. (Veena Shenoy, Sheetal Mahendher, 2020) have found that technology adoption has created the revolution in Indian higher education. Most of the higher education in Bangalore has widely adopted the technology and students' involvement is more than the regular class engagement. (GEETIKA SACHDEV, 2020) has discussed that OTT platforms are experiencing high rise in their demand. A recent report made by Nielsen found that during the lockdown, there was $60 \%$ rise in the amount of content people consumed. Furthermore, according to KPMG report, OTT consumption in India could start seeing a shift from the mobile screen to the large TV screen "owing to the lockdown effect with broadband internet". This COVID-19 situation brought everyone to Work from home (WFH). All the employees from major sectors are adapting to this technique. People find it hard to work from home. (P \& Shahid, 2020) research is based on the experience of the people doing WFH. They concluded that the working environment is a key factor that allows people to work. The willingness depends upon the working environment. One of the major common factors is family. Some employees were not able to work when their children and other family members are around. So, keeping factors in mind, the employers should set up a controlled and supportive environment for the employees to make them willing to do work from home to get the best outcome from employees. Apart from the major sectors like tourism, Manufacturing etc., the most affected sector during COVID-19 is the education sector. Students are in a dilemma that what, when, and how to study. (Daniel, 2020) gave a solution to this problem i.e., Asynchronous method of learning. The research done by him shows a positive response as this method is simple for remote teaching. There are many institutes such as India's National Institute of Open Schooling and The UK Open University who had already started using this technique during the COVID19 pandemic. Institutes, teachers, and students should use more flexible and innovative techniques to recover the loss done by COVID-19. (Mohammad Bani Younes, Samer AlZoubi Feb 2015) discussed the impact of technology on society, the advanced technology have wiped the social and moral responsibilities among the society leading to family and personal problems, health issues like obesity, inactivity, lack of desire to work, increase in violence and crime rate. 


\section{RESEARCH METHODOLOGY}

The objective of the research is to know the growing trends in technology, its importance in challenging and difficult times. The research is solely based on both primary (survey) and secondary (articles, journals, blogs, previous reports) data. The survey was conducted among 221 respondents of all ages, occupations and gender and was centric to Indian nationals. The survey totally showed that technology has become the absolute way of combating the situation of pandemic since 2019. From entertainment platforms like Netflix, Amazon Prime to work and e-learning, people are dependent on new innovations and technology.

\section{ANALYSIS \& INTERPRETATION}

- Results from the survey shows that $49 \%$ respondents have agreed to the fact that they are addicted to digital technology/media.

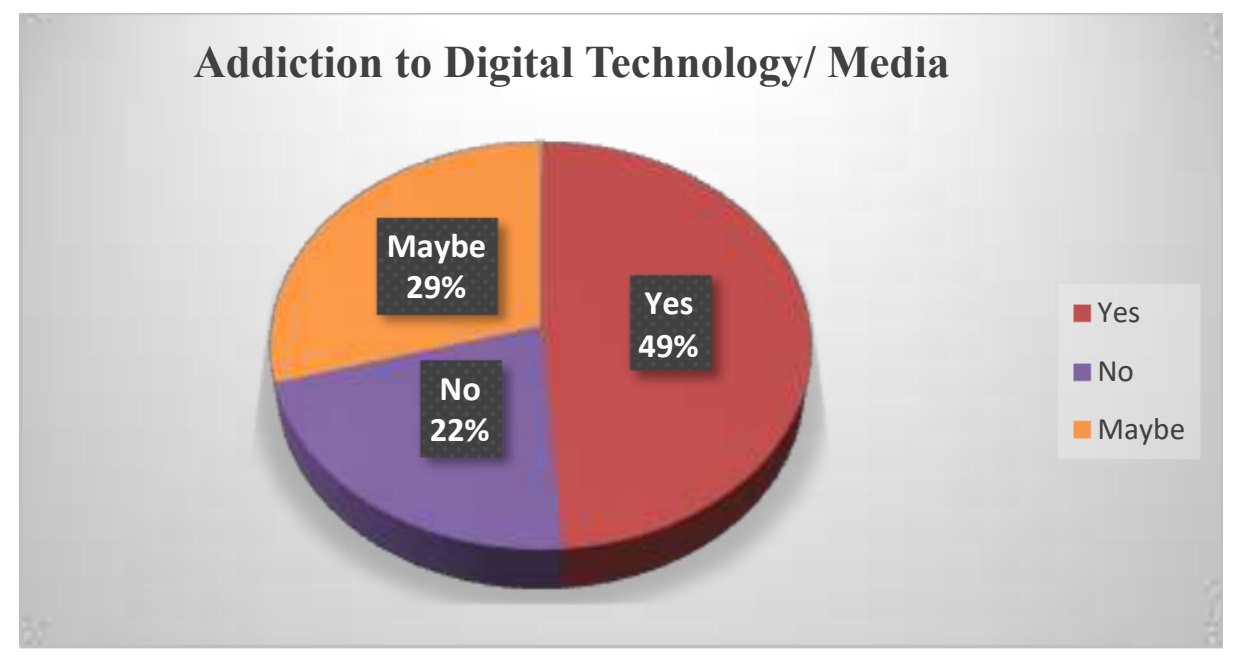

Figure 5 Addiction to Digital Technology/Media

- $42 \%$ respondents spend about 4-8 hours on internet, mobile or digital media on daily basis.

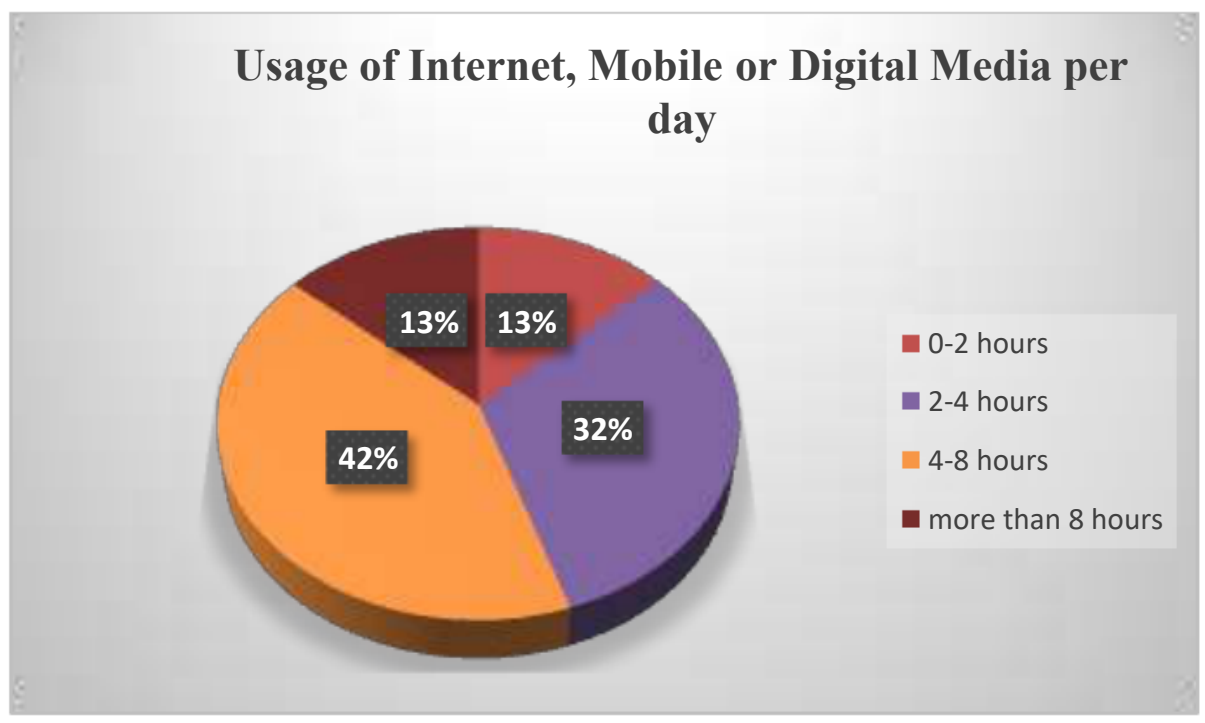

Figure 6 Usage of Internet, Mobile or Digital Media per day 
- $74 \%$ respondents accepted the fact that their life has become more dependable on digital and social media after the outbreak of Covid-19 however, $14 \%$ did not feel the same. The awful impact of ferocious pandemic embedded terror and fear in the lives of people and forced them to stay inside which made them addicted to digital technology.

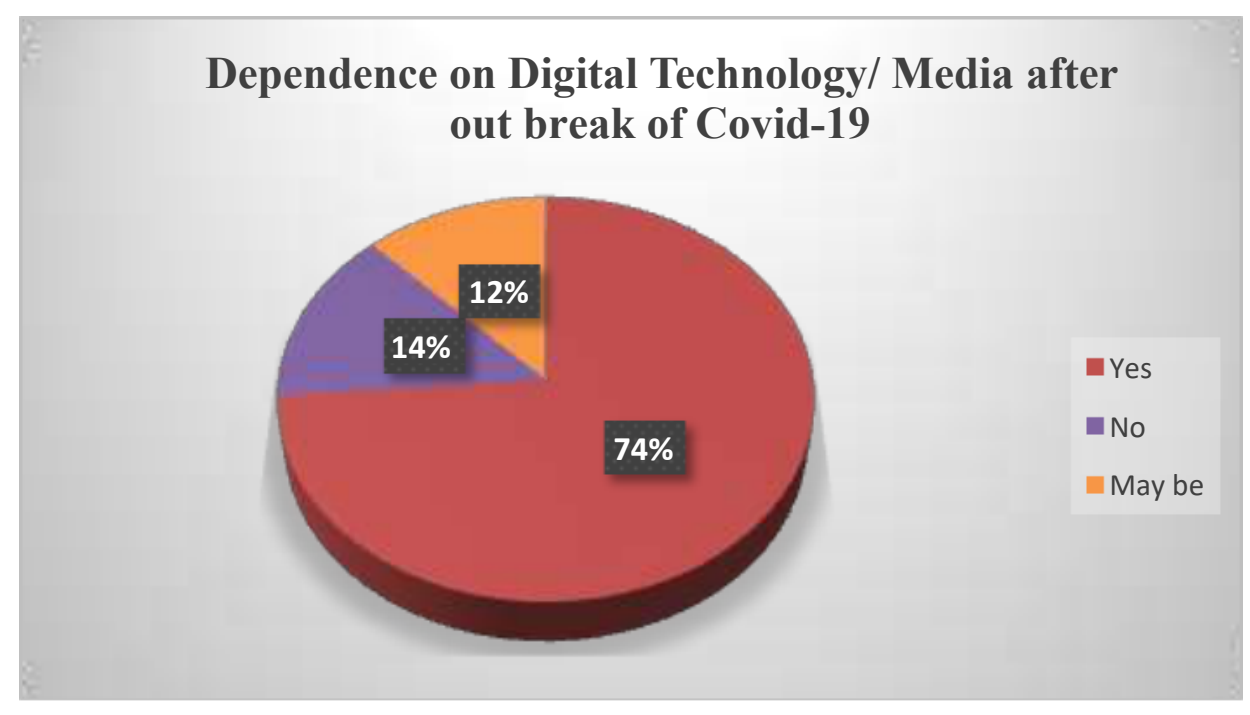

Figure 7 Dependence on digital technology/media after the outbreak of COVID-19

- As the survey was conducted after the outbreak of Covid-19, the statistics shows that the demand for online video conferencing platforms have increased to the level that big companies like Microsoft, Zoom, Skype and others are experiencing high traffic on their apps. Since corporations, enterprises, education institutions are running through video conferencing platforms so, a question was asked from respondents that which video conferencing portal they would prefer for their work or personal entertainment (connecting to families and friends). $32 \%$ respondents preferred Zoom, $22 \%$ preferred Microsoft Teams followed by Google Meet and Skype with 20\% and $12 \%$ respectively.

\section{USAGE OF DIFFERENT VIDEO CONFERENCING PORTALS/SITES}
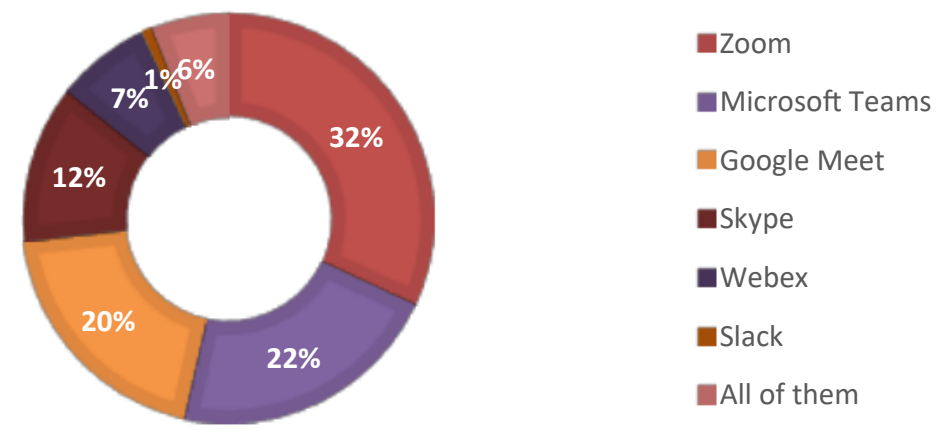

Figure 8 Usage of different video conferencing portals/sites 
- As shown in figure 5,68\% respondents are using e-learning platforms to learn and explore digitally. Many companies and universities have launched certificate courses of short duration, to use the lockdown situation judicially. This has led to networking, along with spread of knowledge.

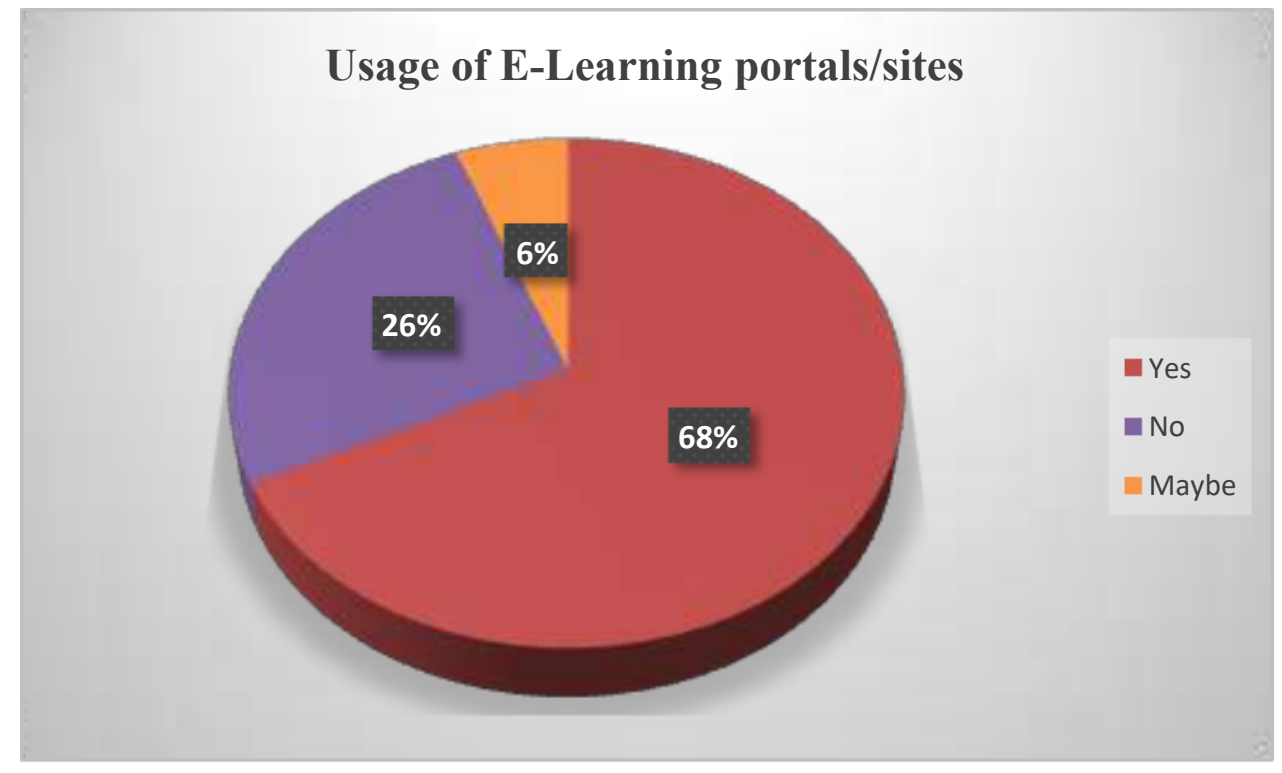

Figure 9 Usage of e-learning portals/sites

- Respondents spend $40 \%$ of their time on live streaming platforms like Netflix, Hotstar etc. $20 \%$ of their time is spent on social media while $20 \%$ of their time is spent on Elearning platforms.

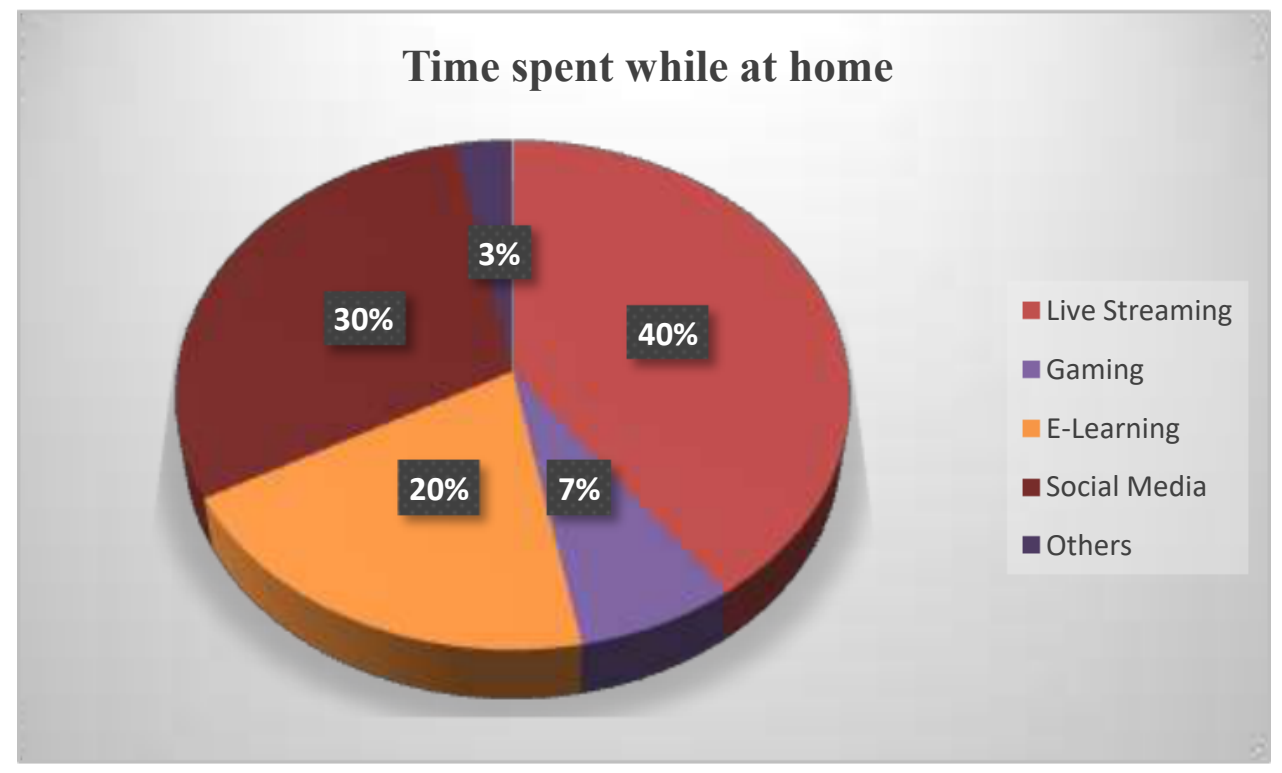

Figure 10 Time spent while at home

- In the time of pandemic many people are facing ill mental and psychological health. To combat this situation $47 \%$ of respondents have subscribed to motivational videos, fitness and meditation channels to cope up with mental health and attain peace of mind during COVID-19. 
Fighting Covid-19 with Technology and Innovation, Evolving and Advancing with Technological Possibilities

\section{Surge in subscription for Motivational videos, Meditation \& Fitness channels}

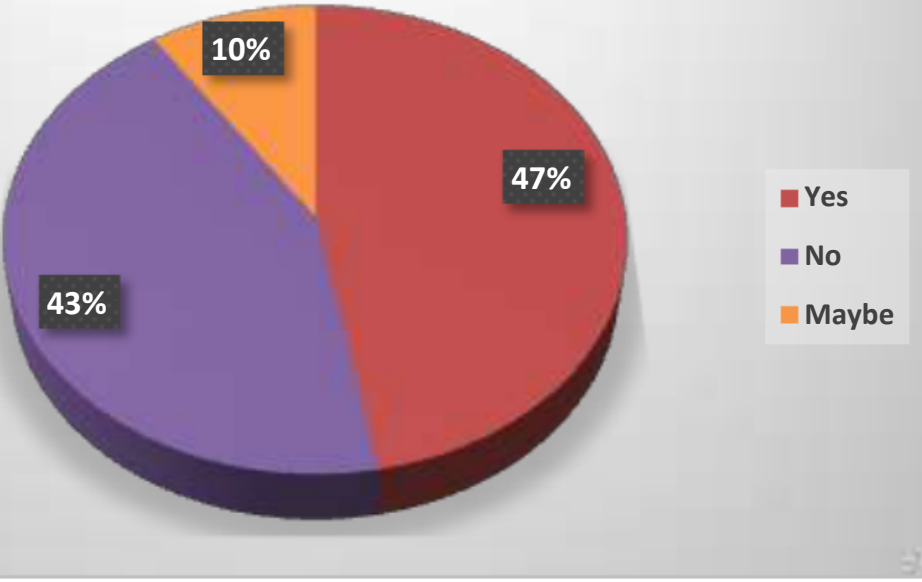

Figure 11 Surge in subscription of channels for motivational videos, meditation \& fitness

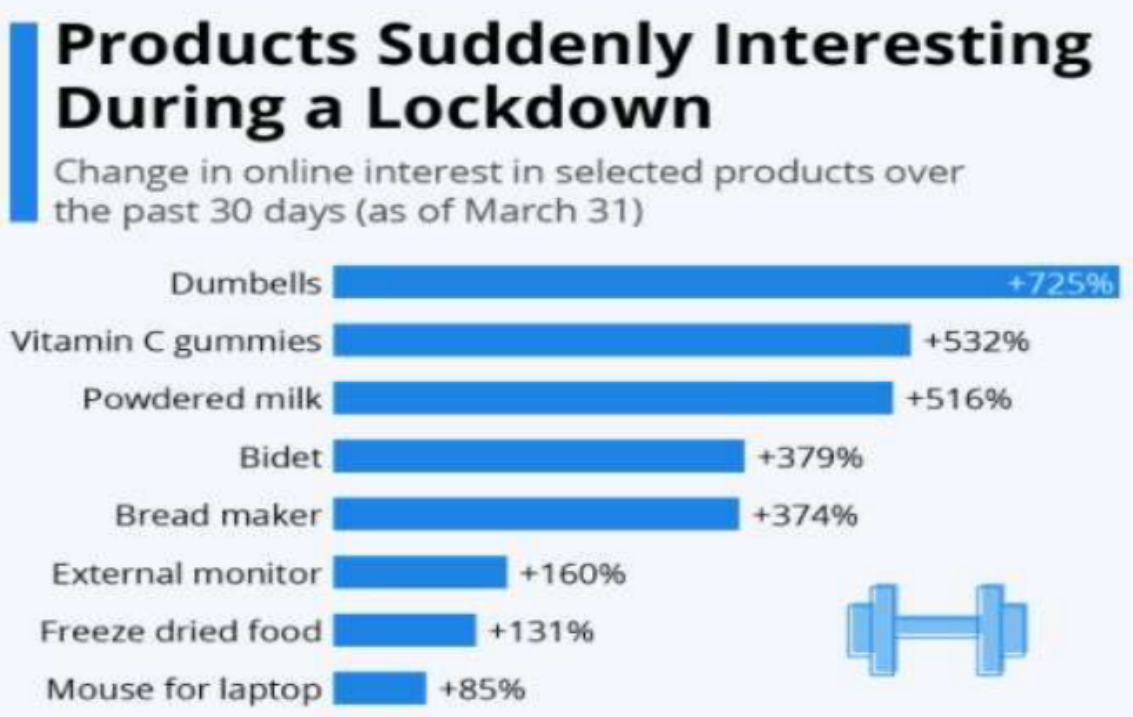

Interest is gauged via "hundreds of millions of consumer behavior signals from across the web". Source: Glimpse

Figure 12

\section{FINDINGS}

While fighting the novel corona virus, new technology and innovations have evolved. Countries across globe are advancing with technological possibilities.

With most of the world's workforce especially the white-collar workers are working from home, students are attending online lectures, health ministries and judiciary are having roundtable conferences while sitting at home, essentials are being delivered at home, entertainment media is boosting their profit. All thanks to the new tech world which supported our lives from the novel corona virus. It wasn't possible at the time of epidemics in 
past as there was no social media, no online portals and even no smart phones, only low speed internet and other technological appliances, still tech helped that time in detecting and fighting against the situation.

We are somewhere blessed with the innovations around us which are helping us in making lemonade from the lemons.

Explosion of Zoom, Microsoft Teams, Google Meet and other online portals

Due to increasing demand of working from home in the pandemic there is an explosion of demand for communication portals from companies like Zoom, Microsoft Teams, Slack etc. But these changes are not short term, these crises may change our working in the future. The "WFH" concept is a boost for all cloud companies and especially the collaboration and meeting tools. Remote work is the new normal which saves commute time and provide much more flexibility.

Mental and psychological apps help in reducing stress and anxiety

The widespread coverage of COVID -19 situation and practice of social distancing made people feel more stressed and anxious. Excess use of smartphones and other digital appliances are making everyone restless. So, to combat the stress and anxiety there are many smartphone apps made available. Multiple digital and wellness apps are now open for free membership. One of them is headspace which provides collection of meditation and mindful content, especially to fight against COVID -19 .

Development of apps to help in detecting Covid-19 symptoms and situations

Many government agencies, universities and companies have launched the apps that are helping to know the real time situation of COVID-19. These apps also provide us updates about number of corona virus cases in our surroundings. Aarogya Setu in India and COVID Symptom Study in UK are the apps provided by the respective government to their natives to track about the contracted people in their surroundings and the current situation of COVID19. These are tracking apps which use the smartphone's GPS and Bluetooth features to track the coronavirus infection.

Digital and contactless payments

India was advancing towards digital economy especially after demonetization. Digital payment is a way of making payments through digital modes. It helps in reducing black money, corruption and is more convenient and easier. Cash may carry the virus within itself, so many contactless and digital payments apps, cards, electronic wallets are recommended by the government to reduce the spread of COVID-19. Digital payments allow the individual to do online money purchases or payments without human interaction.

\section{Distance Learning}

The government in mid of March 2020 announced schools and universities closure due to the increase corona virus risk of impacting the students. Many educational institutions started with the online learning measures so that the lockdown doesn't impact the education of the students. Many technologies were provided by the private companies to learn digitally through cloud computing, like enabling of digital conferencing through MS Teams, Zoom etc. It also included artificial intelligence enabled robotic teachers. Students are provided with online assessments and projects so to keep them engaged and focused. No geographical limitations, knowledge learning, interactive sessions etc. are contributing to new age learning. 
Fighting Covid-19 with Technology and Innovation, Evolving and Advancing with Technological Possibilities

Online Entertainment

Pandemic lead to social distancing and in many cases no human interactions, still the globe is connected through social media. Families separated from each other could contact easily. It helped in providing community and emotional support. Instagram, Facebook, Twitter and YouTube have been entertaining the people all around the globe from providing funny content to factual information. Most of the importance is gained by online streaming services like Netflix, Amazon Prime, Hotstar, HBO Go, Hulu, Sling TV etc. There is huge increase in their demand as they provide endless entertainment through cloud services like online movies, web series, live TV and many more in reasonable subscriptions. The people are entertained and engaged and can chill at their homes with families. Over the top services (OTT) are the emerging platforms which streamed media services through internet directly to the viewers like Amazon prime. Due to corona virus, government have announced the shutdown of cinema halls, gyms, swimming pools, malls, restaurants and large gathering places. So, the launch of new movies is being done through OTT platform.

\section{Fast \& Frugal Innovations}

There was lack of time and resources to fight against this novel pandemic. Every country tried to be as innovative as possible. Trains were made hospital wards for patients with COVID-19. Distilleries have pivoted to produce millions of bottles of hand sanitizers. There were number of fast and frugal innovations like hand sanitizers, low cost PPE kits, masks at nominal prices to name a few.

\section{CONCLUSION}

In this new normal, technology offers solutions to overcome some of the challenges thrown up by the pandemic. This is the new reality, which is predicting growth in virtual meetings, online education, artificial intelligence-based communication, rural broadband, IoT solutions, satellite-based asset tracking solutions, 5G to name a few.

The technology is keeping us connected to our families, offices, friends and near and dear ones. The challenging situation like pandemics doesn't come on one person, it ruins the whole world. To fight against this situation technology has been one of the most important support for survival. With the revolution, the way technology is being used in challenging times have proven to be successful in saving the nation. From entertainment to education it has saved many lives from depression and despair.

All these trends indicate that communication technology will play a great role in reshaping a post Covid-19 world. Our data science has proved its importance and vulnerability to make us survive through difficult situations.

\section{REFERENCES}

[1] Bareq Raad Raheem, A. K. (2020) (PDF) The Role of E-Learning in Covid-19 Crisis. available at: https://www.researchgate.net/publication/340999258_THE_ROLE_OF_ELEARNING_IN_COVID-19_CRISIS (Accessed: 23 July 2020).

[2] Geetika Sachdev (2020) The Rise of OTT Platforms During Covid-19 - The Blue Circle, The Blue Circle. Available at: https://thebluecircle.co/2020/05/01/the-rise-of-ott-platforms-duringcovid-19/ (Accessed: 23 July 2020).

[3] J. A. (2020) Li, J., Hallsworth. A.G. and Coca-Stefaniak, "The Changing Grocery Shopping Behaviour of Chinese Consumers at the Outset of the Covid-19 Outbreak." Tijdschrift voor Economische en Sociale Geografie, [Online]. Available: https://doi.org/10.1111/tesg.12420. 
[4] Kaur, N. (2020). Banking 4.0: "The Influence of Artificial Intelligence on the Banking Industry \& How AI is Changing the Face of Modern Day Banks." 11(6), 577-585. https://doi.org/10.34218/IJM.11.6.2020.049

[5] Mihalis Kritikos (2020) 'Ten technologies to fight coronavirus', European Parliamentary Research Service. available at:

https://www.europarl.europa.eu/RegData/etudes/IDAN/2020/641543/EPRS_IDA(2020)64154 3_EN.pdf

[6] Singh, G., \& Kaur, M. N. (2014). Investigation of the Determinants to Augment Investment in the Indian Stock Market. International Journal of Scientific and Research Publications, 5(1), 2250-3153. www.ijsrp.org

[7] S. J. Daniel, (2020) "Education and the COVID-19 pandemic," Prospects, no. 0123456789, 2020, doi: 10.1007/s11125-020-09464-3.

[8] S. P and M. Shahid, (2020) "Work from home during COVID-19: Employees perception and experiences Dr. Shareena P Mahammad Shahid,” Gjra - Glob. J. Res. Anal., vol. 9, no. 5, pp. 7-10, doi: 10.36106/gjra.

[9] Veena Shenoy, Sheetal Mahendher, N. V. (2020) (PDF) COVID 19 Lockdown Technology Adaption, Teaching, Learning, Students Engagement and Faculty Experience, Mukt Shabd Journal. Available at:

https://www.researchgate.net/publication/340609688_COVID_19_Lockdown_Technology_A daption_Teaching_Learning_Students_Engagement_and_Faculty_Experience (Accessed: 23 July 2020).

[10] Kaur, N. (2018). The Journey of Indian Rupee from 1947 to Present. 08(06), 19-33.

[11] Kaur, M. N., \& Singh, G. (2015). Role of Brokers / Institutional Investors to Induce Investment in Indian Stock Markets. Role of Brokers / Institutional Investors to Induce Investment in Indian Stock Markets, 3(7), 1545-1562.

[12] https://content.techgig.com/top-10-technology-trends-that-will-redefine-a-post-covid-19world/articleshow/75672222.cms

[13] https://www.grabon.in/indulge/featured/most-popular-ott-platforms-in-india/

[14] https://www.microsoft.com/en-us/ai/ai-for-health-covid-data Microsoft

[15] https://m.economictimes.com/small-biz/startups/features/covid-19-cities-lockdown-zoomvideo-calling-app-videoconferencing-google-hangout-skype/articleshow/74767206.cms Economic times.

[16] https://www.statista.com/chart/21297/change-interest-products-lockdown/

[17] https://www.researchgate.net/publication/341757281_Case_Study_Fighting_Covid19_with_Tech_and_Innovation

[18] https://econlife.com/2020/05/pandemic-innovations/ 